\title{
Fishery of Sinop Coasts in the Black Sea Surveys
}

\section{Levent Bat ${ }^{1}$, Fatih Sahin1, Murat Sezgin', Sedat Gonener², Ercan Erdem³, Ugur Ozsandikci}

'Sinop University, Fisheries Faculty, Department of Hydrobiology, Sinop, Turkey

${ }^{2}$ Sinop University, Fisheries Faculty, Department of Fishing Technology and Processing, Sinop, Turkey

${ }^{3}$ General Directorate of Fisheries and Aquaculture, Ministry of Food Agriculture and Livestock, Ankara, Turkey

Please cite this article as: Bat L, Sahin F, Sezgin M, Gonener S, Erdem E, Ozsandikci U. Fishery of Sinop Coasts in the Black Sea Surveys. Eur J Biol 2018; 77(1): 18-25.

\section{ABSTRACT}

Objective: The current work was carried out between 2013-2014 during the fishing periods to evaluate certain fish aggloremations within 3 miles of the coastal zone. Therefore, some basic characteristics of fish populations along the Inceburun coast of the Sinop province of the Black Sea were examined.

Materials and Methods: Data was collected from 5 trawl operations in the Sinop-Inceburun Region of the Black Sea at depths of 20 to 39 meters at 5 different locations. Biometric measurements of each species was made. A literature search was performed to gather information about the status of threatened fish species found in the region. The length-weight parameters of 4 commercial fish species were estimated.

Results: During the fishing season between $1^{\text {st }}$ September 2013 and $15^{\text {th }}$ April 2014 different fish species were captured depending on the season and climate. In these surveys, 16 teleost species from 15 families, 2 elasmobranch species from 2 families and 2 species of invertebrates were recorded from 5 different stations. In these surveys random samples of red mullet, bluefish, horse mackerel, turbot etc. were collected from 5 different stations. The total mean CPUA was estimated at $425.30 \mathrm{~kg} / \mathrm{km}^{2}$.

Conclusion: The Black Sea areas including those around the Sinop coast have an important effect on the entire production of sea fish of the Turkish fishery. In addition, Sinop fisheries generate significant fishery production supporting logistics and employment. In the Sinop peninsula, there is an increasing trend towards the production of commercial species of the Black Sea.

Keywords: Black Sea, Inceburun, Sinop, fishery, bottom trawl

\section{INTRODUCTION}

The Black Sea contains the most isolated of ecosystems of all natural inland seas, connected to the Mediterranean by a very thin waterway through the Turkish Straits. The Black Sea contains a comparatively large variety of marine fauna (1), in spite of its brackish waters $(17 \%)$ and anoxic conditions below a depth of $180 \mathrm{~m}$ (with high levels of $\mathrm{H}_{2} \mathrm{~S}$ ). Approximately 3,800 species have been reported in the Black Sea. $42.9 \%$ of them belong to fungi, algae and higher plants, $52.5 \%$ are invertebrates, $4.5 \%$ fishes and $0.1 \%$ mammals (2).

Fish are one of the tops aquatic organisms which serve as a source of protein $(3,4)$. The fishery industry pays a major role in Turkey's economy as a source of employment and revenue from exports. Turkey has many commercially important marine fishery resources which include demersal and small pelagic fish species. Fish production decreased from 589129 tonnes in 2007 to 301463,6 tonnes in 2016 (5). One of the problems associated with the fishing industry is the over-fishing of commercial fish species throughout the year. Being the most important fishing area, the Black Sea is being developed by the government of Turkey as a fishing center. The Black Sea is heavily influenced by various types of contaminants (6-9). Household and industrial waste are causing great harm to the fishing industry in Turkey. The City of Sinop is one of the most important fishing cities on the Black Sea coast (10). Besides com- 
mercial fishing, recreational fishing is also common in Sinop. Being surrounded by sea on three sides, Sinop is an important area for the fishing industry (10). The fresh catch from marine fisheries is supplied to local fish markets. The national per capita consumption was only $6.2 \mathrm{~kg}$ p.a. in 2015 (5). This value is higher in Turkey's coastal cities including Sinop. Sinop is the center of the fishing industry with many trawlers and fishing vessels using Sinop Fish Harbour. A recent review has pointed out that numerous contaminants, several of which are carcinogenic, and toxic materials such as heavy metals have been found in the marine ecosystem (6). These hazardous pollutants are also moving into the diet of human beings consuming the seafood including fish. However, many recent studies indicate that heavy metals in commercial fish species caught near the Sinop coast are well below the acceptable levels set for EU Commission Regulations and TFC (11-21). In this respect, the fish obtained from Sinop shores are among the better species for consumption.

Although fish constitute only a small portion of the biodiversity of the Black Sea, the main species include anchovy (Engraulis encrasicolus), sprat (Sprattus sprattus), whiting (Merlangius merlangus) and Atlantic bonito (Sarda sarda) which have always been important in the area because of their great commercial value. The current study was carried out between the fishing periods of 2013 and 2014, and several fundamental features of the fish population along the Inceburun coast of the Sinop province of the Black Sea were examined.

\section{MATERIALS AND METHODS}

Samples of fish were taken from waters along the Inceburun coast of the Sinop province in the Black Sea. Samples were collected at depths of between 20-39 m within 3 miles of the coastal zone at 5 different locations using bottom trawling hauls by a fishing vessel during the fishing season of 20132014 (Figure 1).

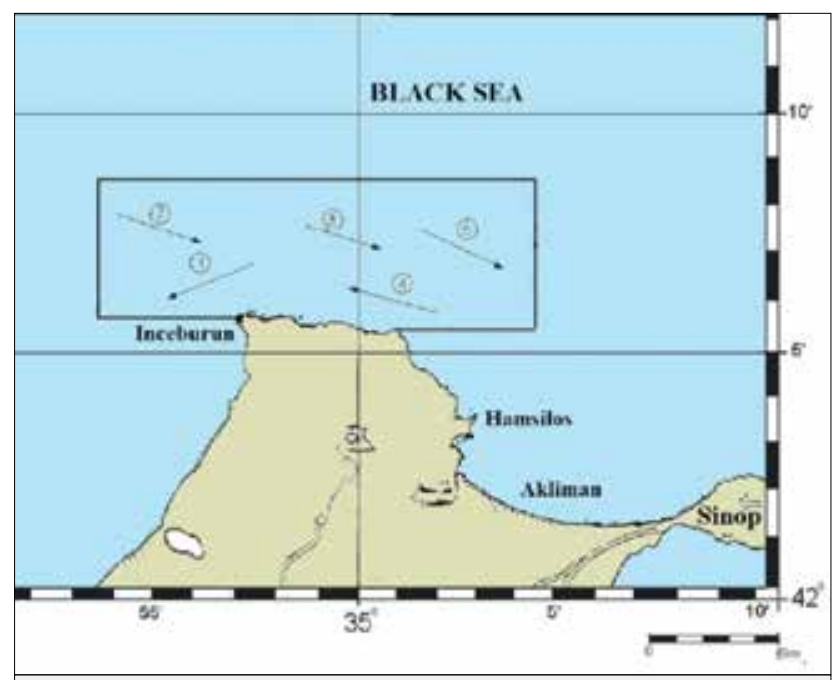

Figure 1. Trawl locations in the Sinop-Inceburun area (Black Sea)
The sizes of the trawl net used were as follows: head rope length - $10 \mathrm{~m}$; mesh size - $44 \mathrm{~mm}$. Haulings were carried out during daylight hours with 30-45 min hauling duration at a vessel speed of $3.66 \mathrm{~km} / \mathrm{h}$ on the ground (Table 1). After each haul, the total catch was sorted and placed into boxes by species. After this process, biometric measurements of each species were taken.

\section{Length-Weight Relationship}

Equation 1 was used to determine length-weight relationship (22):

$$
W=a * L^{b}(1)
$$

where;

W : Weight $(g)$

$\mathrm{L}:$ Total length $(\mathrm{cm})$

$a$ and $b$ : regression coefficients

\section{Fulton's Condition Factor (K)}

$$
K=\frac{W}{L^{3}} * 100
$$

\section{Biomass Estimation}

Biomass was estimated using the swept area method. The swept area, a, can be calculated from equation 2 (24)

$$
\begin{aligned}
& a=D * h r * X 2(2) \\
& D=V * t
\end{aligned}
$$

where:

a : Swept area

$\mathrm{V}$ : Velocity of the trawl over the ground

$\mathrm{X} 2$ : Fraction of the head - rope length

hr: Headrope length

$t$ : Duration of haul

\section{D : Distance covered}

Equation 3 (24) was used for the estimation of relative biomass, the catch per unit of area (CPUA)

$$
C P U A=\frac{C_{w}}{a}(3)
$$

Where;

$$
\begin{aligned}
& \mathrm{a}: \text { Swept area }\left(\mathrm{km}^{2}\right) \\
& \text { Cw : Catch }(\mathrm{kg})
\end{aligned}
$$

Once caught, species were weighed and measured then stored in $4 \%$ formalin for laboratory analysis, excluding bigger fish. Specimens were classified using the identification keys of 
Eur J Biol 2018; 77(1): 18-25

Bat et al. Sinop Fishery Survey

Table 1. Information on trawl operations in the period of 2013-2014 in the Sinop-Inceburun region (Black Sea)

\begin{tabular}{|c|c|c|c|c|c|c|}
\hline \multirow[b]{2}{*}{ Hauls } & \multicolumn{2}{|c|}{ Coordinate } & \multicolumn{2}{|c|}{ Time } & \multirow{2}{*}{$\begin{array}{l}\text { Total Duration } \\
\text { (min) }\end{array}$} & \multirow{2}{*}{$\begin{array}{c}\text { Average Depth } \\
\text { (m) }\end{array}$} \\
\hline & Start & Finish & Start & Finish & & \\
\hline \multirow{2}{*}{1} & $42^{\circ} 7^{\prime} 48.47^{\prime \prime N}$ & $42^{\circ} 7^{\prime} 23.67^{\prime \prime N} \mathrm{~N}$ & \multirow{2}{*}{ 09:45 } & \multirow{2}{*}{$10: 15$} & \multirow{2}{*}{30} & \multirow{2}{*}{39} \\
\hline & $34^{\circ} 57^{\prime} 42.84^{\prime \prime} \mathrm{E}$ & $34^{\circ} 56^{\prime} 36.23^{\prime \prime} \mathrm{E}$ & & & & \\
\hline \multirow{2}{*}{2} & $42^{\circ} 10^{\prime} 44.32^{\prime \prime} \mathrm{N}$ & $42^{\circ} 10^{\prime} 9.83^{\prime \prime} \mathrm{N}$ & \multirow{2}{*}{$11: 10$} & \multirow{2}{*}{$11: 40$} & \multirow{2}{*}{30} & \multirow{2}{*}{20} \\
\hline & $34^{\circ} 53^{\prime} 46.37^{\prime \prime} \mathrm{E}$ & $34^{\circ} 54^{\prime} 42.27^{\prime \prime} \mathrm{E}$ & & & & \\
\hline \multirow{2}{*}{3} & $42^{\circ} 9^{\prime} 41.56^{\prime \prime} \mathrm{N}$ & $42^{\circ} 9^{\prime} 4.59^{\prime \prime} \mathrm{N}$ & \multirow{2}{*}{$12: 35$} & \multirow{2}{*}{ 13:05 } & \multirow{2}{*}{30} & \multirow{2}{*}{29} \\
\hline & $34^{\circ} 57^{\prime} 44.13^{\prime \prime} \mathrm{E}$ & $34^{\circ} 58^{\prime} 36.74^{\prime \prime} \mathrm{E}$ & & & & \\
\hline \multirow{2}{*}{4} & $42^{\circ} 6^{\prime} 15.19^{\prime \prime} \mathrm{N}$ & $42^{\circ} 6^{\prime} 48.04^{\prime \prime} \mathrm{N}$ & \multirow{2}{*}{$14: 35$} & \multirow{2}{*}{$15: 20$} & \multirow{2}{*}{45} & \multirow{2}{*}{34} \\
\hline & $35^{\circ} 2^{\prime} 39.06^{\prime \prime} \mathrm{E}$ & $35^{\circ} 1^{\prime} 42.311^{\prime \prime} \mathrm{E}$ & & & & \\
\hline \multirow{2}{*}{5} & $42^{\circ} 7^{\prime} 56.96^{\prime \prime} \mathrm{N}$ & $42^{\circ} 7^{\prime} 16.19^{\prime \prime} \mathrm{N}$ & \multirow{2}{*}{$16: 10$} & \multirow{2}{*}{$16: 55$} & \multirow{2}{*}{45} & \multirow{2}{*}{35} \\
\hline & $35^{\circ} 2^{\prime} 38.75^{\prime \prime} \mathrm{E}$ & $35^{\circ} 3^{\prime} 21.51^{\prime \prime} \mathrm{E}$ & & & & \\
\hline
\end{tabular}

Table 2. Fish of Sinop coasts during the trawl operations in the period of 2013-2014 in the Sinop-Inceburun region (Black Sea)

\begin{tabular}{lllll}
\hline Class & Ordo & Familia & Species & Common name \\
\hline Chondrichtyes & Myliobatiformes & Dasyatidae & Dasyatis pastinaca & Common stingray \\
\hline & Rajiformes & Rajidae & Raja clavata & Thornback ray \\
\hline Osteichtyes & Perciformes & Mullidae & Mullus barbatus & Red Mullet \\
\hline & Pomatomidae & Pomatomus saltatrix & Bluefish \\
\hline & Carangidae & Trachurus mediterraneus & Horse mackarel \\
\hline & Centracanthidae & Spicara maena & Blotched picarel \\
\hline & Trachinidae & Trachinus draco & Greater weever \\
\hline & Gobiidae & Neogobius melanostomus & Round goby \\
\hline & & Mesogobius batrachocephalus & Toad goby \\
\hline & Uranoscopidae & Uranoscopus scaber & Atlantic stargazer \\
\hline & Sciaenidae & Umbrina cirrosa & Shi drum \\
\hline & Scophthalmidae & Scophtalmus maximus & Turbot \\
\hline & Bothidae & Arnoglossus laterna & Mediterranean scaldfish \\
\hline & Soleidae & Pegusa lascaris & Sand sole \\
\hline Gadiformes & Lotidae & Gaidropsarus mediterraneus & Shore rocking \\
\hline Clupeiformes & Clupeidae & Alosa agone & Twaite shad \\
\hline Scorpaeniformes & Scorpaenidae & Scorpaena porcus & Black scorpionfish \\
\hline Syngnathiformes & Syngnathidae & Hippocampus hippocampus & Sea horse \\
\hline & & &
\end{tabular}

Whitehead et al. (25), Fischer et al. (26) and Bat et al. (27). The specimens caught were classified to the smallest taxon according to the identification key. A Literature study was carried out to gather information on the status of threatened fish species.
In order to gain insight into regional fishing activities and current issues in the region, local fishermen were interviewed to gather information concerning the condition of commercially utilized fish stocks and threatened fish species. Available pub- 
lished papers were examined, particularly for species formerly present in the Sinop coasts of the Black Sea, and additional species were included into the inventory of native ichthyofauna.

Table 3. Calculated Fulton's Condition Factors for 9 fish species from trawl operations in the Sinop-Inceburun region (Black Sea)

\begin{tabular}{lcc}
\hline Species & K & N \\
\hline Mullus barbatus & $1.15 \pm 0.14$ & 188 \\
\hline Pomatomus saltatrix & $0.91 \pm 0.01$ & 100 \\
\hline Trachurus mediterraneus & $0.86 \pm 0.02$ & 56 \\
\hline Uranoscopus scaber & $1.61 \pm 0.03$ & 29 \\
\hline Raja clavata & $1.64 \pm 0.01$ & 28 \\
\hline Scorpaena porcus & $1.93 \pm 0.08$ & 22 \\
\hline Trachinus draco & $0.20 \pm 0.07$ & 8 \\
\hline Gobius melanostomuss & $1.27 \pm 0.05$ & 20 \\
\hline Gobius batrachocephalus & $0.84 \pm 0.04$ & 4 \\
\hline
\end{tabular}

\section{RESULTS}

In the survey; 16 teleost species from 15 families, 2 elasmobranch species from 2 families and 2 species of invertebrates were sampled (Table 2). Fulton's Condition Factor has been calculated and is illustrated in Table 3. The catch per unit area (CPUA) values of sampled fish of trawl operations in the Sinop-Inceburun region are shown in Table 4. The total mean CPUA

is estimated at $425.30 \mathrm{~kg} / \mathrm{km}^{2}$. The minimum, maximum and average length and weight values of each species are shown in Table 5. As tunicates, crabs and seahorses were released back to sea immediately after hauling, only the numbers of those samples were recorded (Table 6).

The main target species of bottom-trawl are whiting (Merlangius merlangus) and red mullet (Mullus barbatus) in the region. Whiting was not recorded in the hauls. Moreover, approximately $90 \%$ of total catch consisted of bycatch. $63 \%$ of the red mullet caught were under the legal catch size which is $13 \mathrm{~cm}$. Furthermore, red mullet was the most abundant species in terms of individual numbers.

Table 4. Estimated CPUA values of fish samples in the Sinop-Inceburun region during the surveys in the fishing period $2013-2014$.

\begin{tabular}{|c|c|c|c|c|c|c|}
\hline \multirow[b]{3}{*}{ Species } & \multicolumn{6}{|c|}{ CPUA $\left(\mathbf{k g} / \mathbf{k m}^{2}\right)$} \\
\hline & \multicolumn{6}{|c|}{ Stations } \\
\hline & I. & II. & III. & IV. & v. & Average \\
\hline Mullus barbatus & 69.02 & 55.30 & 24.54 & 2.33 & 33.92 & $37.02 \pm 11.68$ \\
\hline Pomatomus saltatrix & 70.93 & 2.62 & 0 & 23.13 & 110.05 & $41.35 \pm 21.37$ \\
\hline Trachurus mediterraneus & 18.25 & 5.41 & 2.35 & 7.98 & 1.09 & $7.02 \pm 3.05$ \\
\hline Uranoscopus scaber & 17.54 & 12.46 & 20.38 & 5.94 & 13.37 & $13.94 \pm 2.46$ \\
\hline Dasyatis pastinaca & 8.96 & 470.93 & 50.00 & 59.89 & 182.26 & $154.41 \pm 84.25$ \\
\hline Scorpaena porcus & 0 & 0 & 0 & 25.17 & 0 & 5.03 \\
\hline Neogobius melanostomus & 36.12 & 0.00 & 0.00 & 12.20 & 6.19 & 10.90 \\
\hline Trachinus draco & 0.00 & 7.27 & 1.91 & 0 & 1.46 & 2.13 \\
\hline Mesogobius batrachocephalus & 17.87 & 0 & 0 & 0 & 0 & 3.58 \\
\hline Scophthalmus maximus & 0 & 2.62 & 12.57 & 3.39 & 0 & 3.71 \\
\hline Umbrina cirrosa & 0 & 44.64 & 17.49 & 0 & 0 & 12.43 \\
\hline Spicara maena & 0 & 0 & 0 & 0.40 & 1.09 & 0.30 \\
\hline Raja clavata & 493.83 & 0 & 0 & 128.93 & 39.78 & 132.51 \\
\hline Pegusa lascaris & 0 & 1.75 & 0 & 0 & 0 & 0.35 \\
\hline Arnoglossus laterna & 0 & 0 & 0 & 0.55 & 0 & 0.11 \\
\hline Gaidropsarus mediterraneus & 2.62 & 0 & 0 & 0 & 0 & 0.52 \\
\hline Total & 735.14 & 603.01 & 129.23 & 269.91 & 389.22 & $425.30 \pm 109.69$ \\
\hline
\end{tabular}


Table 5. Total length and weight values (means \pm SE) of fish species obtained from trawl operations in the Sinop-Inceburun region (Black Sea)

\begin{tabular}{|c|c|c|c|c|c|c|c|}
\hline Species & $\mathbf{N}$ & $\begin{array}{l}\text { Min. } \\
\text { Length }(\mathrm{cm})\end{array}$ & $\begin{array}{c}\text { Max. } \\
\text { Length }(\mathrm{cm})\end{array}$ & Mean \pm SE & $\begin{array}{c}\text { Min. } \\
\text { Weight (gr) }\end{array}$ & $\begin{array}{c}\text { Max. } \\
\text { Weight (gr) }\end{array}$ & Mean \pm SE \\
\hline Mullus barbatus & 188 & 3.8 & 18.5 & $12.07 \pm 0.18$ & 2 & 64 & $19.78 \pm 0.84$ \\
\hline Pomatomus saltatrix & 100 & 12 & 22.9 & $17.43 \pm 0.21$ & 12 & 110 & $50.02 \pm 1.81$ \\
\hline Trachurus mediterraneus & 56 & 8 & 18 & $11.18 \pm 0.26$ & 3 & 58 & $12.95 \pm 1.07$ \\
\hline Uranoscopus scaber & 29 & 9.5 & 20.4 & $14.1 \pm 0.46$ & 12 & 150 & $50.07 \pm 5.72$ \\
\hline Raja clavata & 28 & 20 & 46 & $31.64 \pm 1.11$ & 121.83 & 1699.58 & $583.76 \pm 67.02$ \\
\hline Scorpaena porcus & 22 & 8.5 & 17 & $11.67 \pm 0.40$ & 15 & 62 & $31.41 \pm 2.64$ \\
\hline Neogobius melanostomus & 20 & 11.4 & 22.8 & $15.96 \pm 0.57$ & 20 & 170 & $58.3 \pm 7.03$ \\
\hline Trachinus draco & 8 & 11 & 18 & $15.86 \pm 0.41$ & 15 & 35 & $26 \pm 1.23$ \\
\hline Mesogobius batrachocephalus & 4 & 20.5 & 22.2 & $21.3 \pm 0.13$ & 70 & 105 & $81.75 \pm 2.93$ \\
\hline Scophthalmus maximus & 3 & 15 & 24 & $19.3 \pm 0.84$ & 48 & 93 & $70.5 \pm 5.91$ \\
\hline Umbrina cirrosa & 2 & 20 & 42 & $31 \pm 2.89$ & 200 & 817 & $508.5 \pm 81.02$ \\
\hline Spicara maena & 2 & 9.5 & 15 & $12.25 \pm 0.72$ & 11 & 30 & $20.5 \pm 2.49$ \\
\hline Dasyatis pastinaca & 3 & 40 & 78 & $58.67 \pm 3.53$ & 63.79 & 9036.68 & $4555.94 \pm 757.54$ \\
\hline Pegusa lascaris & 1 & - & - & 16.5 & - & - & 32 \\
\hline Arnoglossus laterna & 1 & - & - & 12.5 & - & - & 15 \\
\hline Gaidropsarus mediterraneus & 1 & - & - & 19 & - & - & 48 \\
\hline
\end{tabular}

Table 6. Numbers of Tunicates, Sea horses and Crabs by Stations.

\begin{tabular}{|c|c|c|c|c|c|c|}
\hline Species & I. Station & II. Station & III. Station & IV. Station & V. Station & Total \\
\hline Ascidia aspersa (Tunicate) & 320 & 18 & - & - & - & 338 \\
\hline Hippocampus hippocampus (Seahorse) & 11 & 2 & 1 & - & - & 14 \\
\hline Liocarcinus depurator (Crab) & 63 & 124 & 80 & 250 & 95 & 612 \\
\hline
\end{tabular}

Length-Weight relationships of sampled fish which were of sufficient sample size are illustrated in Figure 2. Red mullet, horse mackerel (Trachurus mediterraneus) and black scorpionfish (Scorpaena porcus) showed negative allometric growth while bluefish showed isometric growth. The average length values of red mullet which is the target species of demersal trawl were as follows; $12.01 \mathrm{~cm}, 12.06 \mathrm{~cm}, 10.75 \mathrm{~cm}, 10.15 \mathrm{~cm}, 13.89 \mathrm{~cm}$ respective to station number. The average length of red mullet specimens caught in Station V was significantly higher than those derived from other stations according to the One-Way Anova statistical test $(p<0.05)$.

\section{DISCUSSION AND CONCLUSION}

In the present study bottom trawler fishing in the region of the Sinop coast reveals very small numbers of the target species. The majority of commercial fish species were Red mullet followed by Turbot (Scophtalmus maximus) and Thornback Ray (Raja clavata) (see Table 4).

Rays and sharks are usually seen as unwanted fish species which are discarded due to the fact that they are not consumed in the domestic market. Several pelagic fish species such as Bluefish (Pomatomus saltatrix) and Twaite shad (Alosa agone), are also accidentally caught in bottom trawl fisheries but they are generally discarded excluding those large enough to be commercially marketed.

Sinop which is located on the Boztepe Peninsula is the northernmost point of the Turkish Black Sea coast and is referred to as the midpoint of the Black Sea. The fact that three sides of the city of Sinop are surrounded by the Black Sea has made fishing an important industry. Gerze, Ayancik and Türkeli are seaside districts of Sinop provincial (10). 

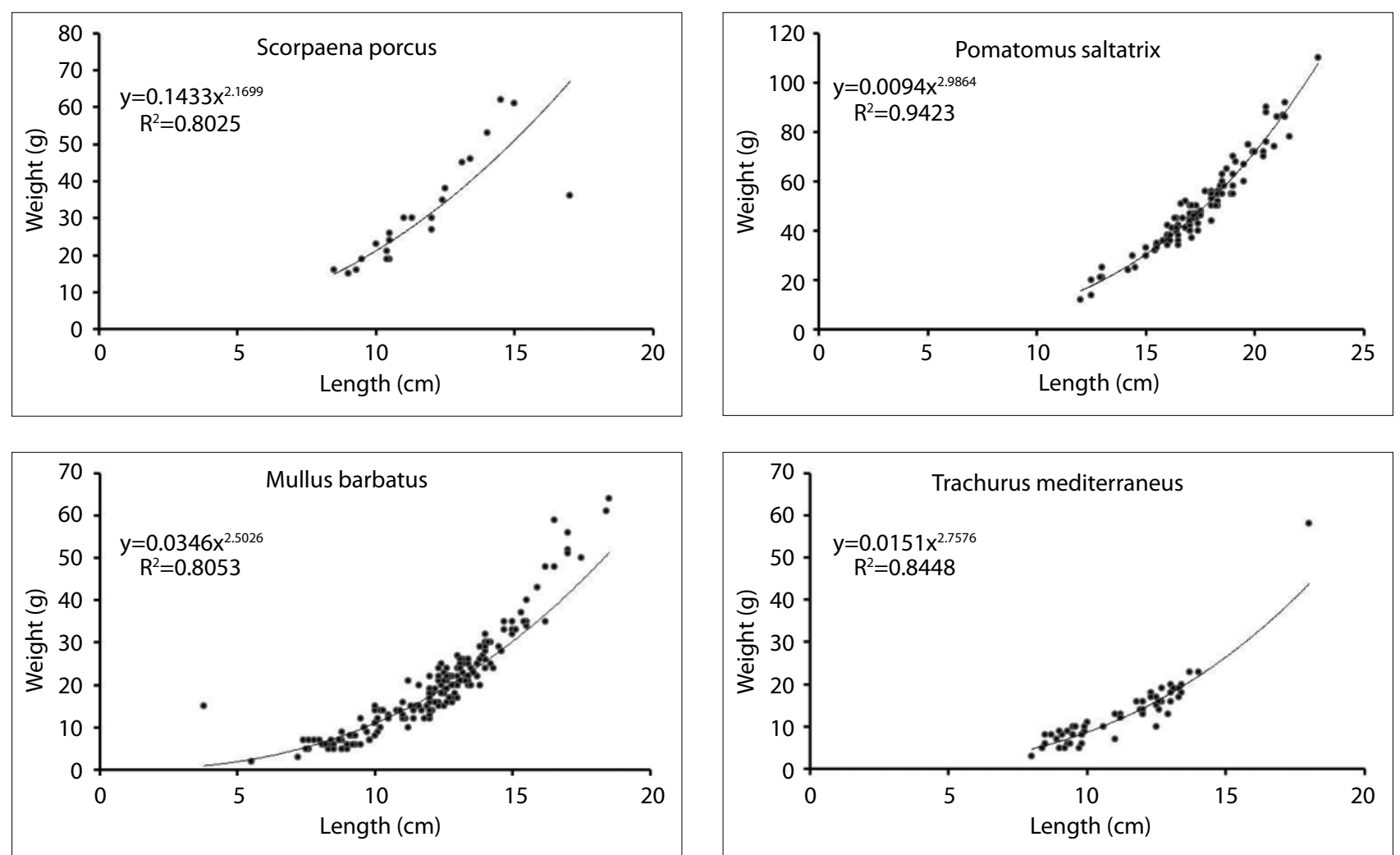

Figure 2. Length-weight relationships for S. porcus, P. saltatrix, M. barbatus and T. mediterraneus from the Sinop-Inceburun (Black Sea) during the trawl surveys in the fishing period 2013-2014.

Commercial fishing is carried out in two ways; large-scale (purse seine and trawl fisheries) and small- scale (fishing boats smaller than $12 \mathrm{~m}$ which operate gillnet, fishing line etc.). A considerable amount of the anchovy captured in the Black Sea is along the Sinop coast.

The length-weight relationship is widely used in the analysis of fishery data $(28,29)$, mostly because of the difficulty and time required to record weight in the field (30). The relationship is often used to convert growth-in-length equations for prediction of weight-at-age and used in stock assessment models (31), to calculate condition indices (32) and for lifetime and morphological comparison of populations from various regions (33). In the equation; $b=3$ refers to isometric growth, $b<3$ or $b>3$ refers to allometric growth.

Data concerning the marine fish of the Sinop coast is limited. Information on local fish faunas is scarce. A total of 94 species of 44 families along the Sinop - Samsun coastline have been identified (34). Gönener and Bilgin (35) reported that whiting, horse mackerel, red mullet, turbot, black scorpion fish, Thwaite shad, picarel (Spicara maena), picked dogfish (Squalus achantias), thornback ray and goby (Gobius sp.) were sampled with bottom-trawl in the Sinop-Inceburun area during the 2007 and 2008 fishing seasons. Similarly, Gönener and Özdemir (36) studied annual, monthly and daily catch amounts from the Sinop-Inceburun region during the 2008 and 2009 fishery seasons. They found whiting, red mullet, turbot, shad, picarel, horse mackerel, shark and goby (Gobius sp.) in the same region of the Black Sea. Sampled species are similar to the current study except for whiting. Whiting could not be caught in our study, which may be due to the fact that the hauling was performed in shallow waters.

A sum of 3455 authorized fishermen and 536 fishing boats are present in the Sinop region with ports like Gerze and Ayancık (37). Fishing operations continue throughout the year depending on with meteorologic conditions and the fishing season lasts between 60 and 270 days. The quantity of catch varies. The areas in which seaside fishing operations take place are Akliman, Sarıkum, Inceburun and Gerze (Çakıroğlu) (37).

As a consequence of eutrophication caused by a rise in the influx of nutrients from large northwest rivers over the past several decades, the Black Sea environment has changed considerably. The effects of the change in nutrient levels can be seen in the quality of biota with the inclusion of ichthyofaunal (34). The Black Sea has a fairly straight continental shelf and very weak oxygenated surface thickness and a eutrophic structure which provides a habitat for pelagic fishes. There is an increase in the fish composition caught at depths in which small pelagic fish constitute more than $90 \%$ of the total amount (38). Bottom trawls are an extremely effective fishing technique in demersal fishing with a catch rate of $60 \%$ (39). The most profitable sea yields off the Black sea coasts include pelagic species such as anchovy, horse mackerel, sprat, bluefish, bonito, benthic fish such as red mul- 
let, whiting, turbot as well as and sea snails and mussels, (40). The fish caught in the Sinop area are generally of similar species. Moreover, the Black Sea, particularly around the Sinop shores is one of the best spawning fields for whole commercial fish species, including predator species, which migrated for spawning or feeding (34). It is indicated that marine fishery accounts for $76 \%$ of the total production of Turkish fisheries in 2007 (41). With respect to TUIK (5) anchovy accounts for $67 \%$ of the Black Sea fishing catch and $49 \%$ of fisheries in Turkey. Thus, variations in the distribution of anchovy and the amount of catch in any given fishing season have a serious influence on overall yearly fishing quantity (40). To support the fishing industry, the Turkish Government have implemented 1) a tax relief scheme for the diesel oil used in fishing vessels and 2) a subsidized credit scheme for fishermen (35). Gücü (38) claimed that reducing the expense of fishing has, to some extent, eased the situation for the fisheries, however, on the other hand, it has had a harmful effect on fish stocks. In general, fishing in Turkey, including in the Sinop region, operates on a diurnal basis, fishing in deep waters during the day and then returning to harbor (42). Moreover, it is rather apparent that the Black Sea area including the Sinop coast has a substantial effect on total production of marine fish of Turkish fisheries and Sinop fisheries constitute an important fishery industry and contribution to employment. There is an improvement in the availability of catch and biological data for economic species caught from the Sinop coast of the Black Sea. It should be noted that bio-ecologic information on capture and working statistics for all commercial fishing is still extremely limited. Therefore, it is suggested that further research to be carried out before any outcome is drawn.

Acknowledgement: This study was made possible by the contribution of European Community's Seventh Framework Programme (FP7/2007-2013) under Grant Agreement No. 287844 for the project "Towards COast to COast NETworks of marine protected areas (from the shore to the high and deep sea), coupled with sea-based wind energy potential" (COCONET).

Conflict of Interest: The authors have no conflict of interest to declare.

\section{REFERENCES}

1. Bat L, Sezgin $M$, Satılmış HH, Şahin F, Üstün F, Birinci-Özdemir $Z$, Gökkurt-Baki O. Biological diversity of the Turkish Black Sea coast. Tu J Fish Aqua Sci 2011; 11: 683-92.

2. Zaitsev Yu, Mamaev V. Marine Biological Diversity in the Black Sea: A Study of Change and Decline. New York, USA Uni Nat Publ 1997; $208 \mathrm{pp}$.

3. EFSA NDA Panel (EFSA Panel on Dietetic Products, Nutrition and Allergies). Scientific Opinion on health benefits of seafood (fish and shellfish) consumption in relation to health risks associated with exposure to methylmercury. EFSA J 2014; 12 (7): 761-80.

4. EFSA Scientific Committee. Statement on the benefits of fish/seafood consumption compared to the risks of methylmercury in fish/ seafood. EFSA J 2015; 13(1): 3982, 36 pp.

5. TUIK, Turkish Fishery Statistics 2016. http://www.tuik.gov.tr/

6. Bat L. Heavy metal pollution in the Black Sea. In: Düzgüneş E, Öztürk B, Zengin $M$, editors. Turkish Fisheries in the Black Sea. Istanbul: Tu Mar Res Found 2014; 71-107. ISBN: 987-975-8825-32-5
7. Bat L, Özkan EY. Heavy metal levels in sediment of the Turkish Black Sea coast. In: Bikarska I, Raykov V, Nikolov N, editors. Progressive Engineering Practices in Marine Resource Management. USA: IGI Glo book ser Adv in Environ Eng and Green Techn (AEEGT) 2015; 399-419.

8. Bat L, Özkan EY, Öztekin HC. The contamination status of trace metals in Sinop coast of the Black Sea, Turkey. Caspian J Environ Sci 2015; 13 (1): 1-10.

9. Bat L, Özkan EY, Büyükisik HB, Öztekin HC. Assessment of metal pollution in sediments along Sinop peninsula of the Black Sea. Int J Mar Sci 2017; 7(22): 205-13. [CrossRef]

10. Bat L, Sezgin M, Şahin F, Birinci Özdemir Z, Ürkmez D. Sinop city fishery of the Black Sea. Mar Sci 2013; 3(3): 55-64.

11. Bat $L$, Arıcı E. Health risk assessment of heavy metals in Sarda sarda Bloch, 1793 for people through consumptionfrom the Turkish Black Sea coasts. Int J Zoo Res 2016; 1(1): 01-07.

12. Bat $L$, Arıcı $E$, Sezgin $M$, Şahin F. Heavy metals in edible tissues of benthic organisms from Samsun coasts, South Black Sea, Turkey and their potential risk to human health. J Food Health Sci 2016; 2 (2): 57-66. [CrossRef]

13. Bat $L$, Arıcı $E$. Heavy metal levels in tissues of Merlangius merlangus (Linnaeus, 1758) from the Black Sea coast of Turkey and potential risks to human health. Int J Mar Sci 2016; 6 (10): 1-8.

14. Bat L, Öztekin HC. Heavy metals in Mytilus galloprovincialis, Rapana venosa and Eriphia verrucosa from the Black Sea coasts of Turkey as bioindicators of pollution. Walailak J Sci and Tech 2016; 13 (9): 715-28.

15. Bat L, Arıcı E, Sezgin M, Şahin F. Heavy metal levels in commercial fishes caught in the southern Black Sea coast. Int J Environ and Geoinfor 2017; 4 (2): 94-102. [CrossRef]

16. Bat $L$, Arıcı E, Ürkmez D. Heavy metal levels in the Black Sea sprat (Sprattus sprattus). Int J Res Agric and Forest 2017; 4 (6): 1-8.

17. Commission Regulation (EC). Setting maximum levels for certain contaminants in foodstuffs. Official J Euro Uni 2006; L 364: 5-24

18. Commission Regulation (EC). No 1275/2013 of 6 December 2013 amending Annex I to Directive 2002/32/EC of the European Parliament and of the Council as regards maximum levels for arsenic, cadmium, lead, nitrites, volatile mustard oil and harmful botanical impurities. Official J Eur Uni 2013; L 328: 86-92.

19. Commission Regulation (EC). Amending Regulation (EC) No $488 / 2014$ as regards maximum levels of cadmium in foodstuffs. Official J Eur Uni 2014; L 138: 75-9.

20. Commission Regulation (EC). Amending Regulation (EC) No $1881 / 2006$ as regards maximum levels of lead in certain foodstuffs. Official J Eur Uni 2015; 161: 9-13.

21. TFC. Notifications about determination of the maximum levels for certain contaminants in foodstuffs of Turkish Food Codex. Official Gaz Rep Turkey 2002; Notification No: 2002/63, Issue: 24885. (inTurkish).

22. Ricker WE. Computations and Interpretation of Biological Statistics of Fish Populations. Bull Fish Res Board Canada 1975; 191 : $1-382$.

23. Pauly D. Fish Population Dynamics in Tropical Waters: A Manual for Use With Programmable Calculators. ICLARM Studies and Reviews 8, International Center for Living Aquatic Resources Management, Manila, 1984; 325pp.

24. Sparre P, Venema SC. Introduction to Tropical Fish Stock Assessment, Part I:Manual. FAO Fish Tech Pap 1998; No 306/1 Rev.2 Rome, FAO. 1998. 407p.

25. Whitehead PJP, Bauchot ML, Hureau JC, Nielsen J, Tortonese E. Fishes of the Northeastern Atlantic and the Mediterranean. Paris UNESCO $1984 ; 1473$ pp. 
26. Fischer W, Bauchot ML, Schneider M. Fiches FAO d'identification des espèces pour les besoins de la pêche. Méditerranée et mer Noire (Zone de pêche 37). Rome FAO and EEC 1987 ; 761-1530.

27. Bat L, Erdem Y, Ustaoglu-Tırıl S, Yardim Ö. Fish Systematic. Nobel Yay Dag Ltd. Sti Ankara 2011; 272 pp. ISBN: 978-605-133-116-4 (in Turkish).

28. Yankova $\mathrm{MH}$, Pavlov D, Ivanova $\mathrm{P}$, Karpova $\mathrm{E}$, Boltachev $\mathrm{A}$, Öztürk $B$, et al. Marine fishes in the Black Sea: recent conservation status. Medit Mar Sci 2014; 15(2): 366-79. [CrossRef]

29. Zarrad R, Missaoui H. Morphometric relationships of fattening bluefin tuna (Thunnus thynnus) caught in the central mediterranean in 2013 and 2014. Collect Vol Sci Pap ICCAT 2017; 73(6): 2188-94.

30. Andrade HA, Camos RO. Allometry coefficient variations of the length-weight relationship skipjack tuna (Katsuwonus pelamis) caught in the southwest South Atlantic. Fish Res 2002; 55: 307-12. [CrossRef]

31. Pauly D. Fishbyte Section Editorial. ICLARM Quart Naga 1993; 16: 26p.

32. Anderson R, Gutreuter $\mathrm{S}$. Length, weight and associated structural indices. In: Nielsen L, Johnson D. editors. Fisheries Techniques. Bethesda: American Fish Soc 1983; 283-300.

33. Petrakis G, Stergiou KI. Weight-length relationship for 33 fish species in Greek waters. Fish Res 1995; 21: 465-9. [CrossRef]

34. Bat L, Erdem Y, Ustaoğlu S, Yardım Ö, Satılmış HH. A Study on the Fishes of the Central Black Sea Coast of Turkey. J Black Sea/Med Environ 2005; 11 (3): 287-302.
35. Gönener S, Bilgin S. The Distribution and Biomass of Catchable Fish Caught by Commercial Bottom Trawl in the Black Sea (Sinop-Inceburun Region). J FishSci.com 2010; 4 (3); 195-208. doi:10.3153/ jfscom.2010021 (in Turkish). [CrossRef]

36. Gönener S, Özdemir S. The Biomass and Density Changes of Catchable Fish Caught by Bottom Trawl in the Black Sea (Sinop-Inceburun Region). J FishSci.com 2013; 7(2): 125-40.

37. Anonymous. Fisherman Boats and Fishery Statistics in 2010. Ministry of Agriculture, Sinop Provincial Directorate, Sinop. 2010. (in Turkish).

38. Gücü AC. Small pelagic fish and fisheries in Turkey. In: Tokaç A, Gücü AC, Öztürk B, editors. The state of the Turkish fisheries. Istanbul: Tu Mar Res Found 2012; 1-17

39. Kaykaç MH, Tosunoglu Z, Tokaç A. Trawl fisheries. In: Tokaç A, Gücü AC, Öztürk B, editors. The state of the Turkish fisheries. Istanbul: Tu Mar Res Found 2012; 316-28.

40. Ak O, Genç Y. The Black Sea Fishery. In: Tokaç A, Gücü A.C, Öztürk $B$, editors. The state of the Turkish fisheries. Istanbul: Tu Mar Res Found 2012; 182-213.

41. Anonymous. Environmental indicators 2008. Department of Environmental Inventory, Ankara: Rep Tu Min Environ and Forest 2009; $36 \mathrm{pp}$.

42. Tokaç A. Classification of commercial fishing gears and methods in Turkish fisheries. In: Tokaç A, Gücü A.C, Öztürk B, editors. The state of the Turkish fisheries. Istanbul:Tu Mar Res Found 2012; 154-81. 